\title{
SOME 2-ARYLBENZIMIDAZOLE DERIVATIVES AS AN ANTIMALARIAL AGENT: SYNTHESIS, ACTIVITY ASSAY, MOLECULAR DOCKING AND PHARMACOLOGICAL EVALUATION
}

\author{
B. Purwono ${ }^{1, \bowtie}$, B. A. Nurohmah ${ }^{1}$, P. Z. Fathurrohman ${ }^{1}$ and J. Syahri ${ }^{2}$ \\ ${ }^{1}$ Department of Chemistry, Faculty of Mathematics and Natural Sciences, Universitas Gadjah \\ Mada, 55281, Yogyakarta, Indonesia. \\ ${ }^{2}$ Department of Chemistry, Faculty of Mathematics and Natural Sciences, Universitas \\ Muhammadiyah Riau, 28156, Pekanbaru, Indonesia. \\ ${ }^{{ }}$Corresponding Author: purwono.bambang@ugm.ac.id
}

\begin{abstract}
A series of some 2-arylbenzimidazole derivatives have been synthesized from substituted aryl aldehyde and ophenylenediamine using microwave radiation and tested for its antimalarial activity. The 2-(4-methoxyphenyl)- $1 \mathrm{H}$ benzimidazole showed excellent in vitro antimalarial activity toward Plasmodium falciparum (3D7) strain. Molecular docking studies have supported in vitro antimalarial assay. This compound also showed good bioavailability and druglike properties.
\end{abstract}

Keyword: Antimalarial, 2-arylbenzimidazole, Docking, Bioavailability, Plasmodium falciparum.

RASĀYAN J. Chem., Vol. 14, No.1, 2021

\section{INTRODUCTION}

Malaria is still a serious problem in the world. In 2016, 216 million cases and 445 thousand death in 91 countries have been reported by the World Health Organization (WHO). ${ }^{1}$ The number of malaria infections keeps high as in 2018 with 228 million cases and 405,000 mortality. ${ }^{2}$ Some drugs have been developed to cure malaria such as artemisinin, chloroquine, and quinine. Nevertheless, in recent years, Plasmodium has been reported to show resistance to almost all the common drugs. ${ }^{3}$ Therefore, searching for new antimalarial compounds by synthetic approach or isolation from natural products has become the popular research. ${ }^{4}$ Substituted benzimidazoles or fused benzimidazoles have been reported with some biological activities such as antiulcer ${ }^{5}$, anticancer ${ }^{6}$, antimalarial ${ }^{7-10}$, antimicrobial ${ }^{8,9}$, antivirus ${ }^{8}$ and antidiabetic ${ }^{8}$. Recently, antimalarial activity to P.falciparum strain (3D7) from benzimidazole acrylonitrile derivatives was reported by the $\mathrm{IC}_{50}$ value of $0.69-72.17 \mu \mathrm{M} .{ }^{10}$ Camacho et al. ${ }^{11}$ have reported the series of benzimidazoles with antimalarial activity as good as chloroquine (CQ) through the inhibition of $\beta$-hematin formation. Benzimidazole derivatives were also reported to show less toxicity toward VERO-76 cell lines. ${ }^{12,13}$ Hence, the development and discovery of drugs for antimalaria from benzimidazoles are promising.

The development of the drug compound needs to consider the type of functional groups attached to the compounds, as it might lead to different chemical interactions and bioactivity. Sharma et al. ${ }^{14}$ have reported the structure-activity relationship of benzimidazole-substituted acrylonitriles as antimalaria. Their work suggested that substitution of the methoxy group in the substituted-phenyl acrylonitrile can give a good influence on antimalarial activity, while the hydroxyl group also can give a good effect on antimalarial activity when it binds in certain positions. The presence of methoxy was also reported to significantly increase the antimalarial activity in chalcone and coumarin derivatives. ${ }^{15,16}$ The work by Mueller et al. ${ }^{10}$ has highlighted that the substitution of a cyclic group than acyclic in position 2 of benzimidazoles could increase the antimalarial activity.

Compounds with high activity are one of the important aspects of the pharmacological design of the drug besides the bioavailability, toxicity, pharmacokinetics, and drug-drug interactions. ${ }^{17}$ Pharmacological parameters ( $\log \mathrm{P}$, number of hydrogen bond donors and acceptors) are important to determine the 
pharmacokinetics of the drug in the human body including absorption, distribution, metabolism, and excretion (ADME). ${ }^{18}$ Drug-like properties in the early preclinical stage can be predicted by computational studies. Lipinski's rule of five can be used to predict molecules likely orally active as drugs in humans. Some studies have reported a good prediction of the pharmacokinetic profile for benzimidazole. ${ }^{18-20}$

In this study, we prepared four 2-arylbenzimidazoles (1-4) derivatives bearing hydroxyl and methoxy groups in different positions of 2-aryl substitution. These benzimidazole derivatives can be prepared from substituted arylaldehyde and o-phenylenediamine as the starting material using microwave irradiation. In vitro antimalarial activity was performed against P.falciparum (3D7) strain. Molecular docking was performed to the synthesized compounds and binding site of wild-type Plasmodium falciparum dihydrofolate reductase-thymidylate synthase (PfDHFR-TS) protein (1J3I.pdb). Meanwhile, the drug-like properties of benzimidazoles 1-4 were determined based on Lipinski's rule of five from ADME analyses.

\section{Materials and Instrumentations}

\section{EXPERIMENTAL}

The chemicals used in the synthetic step were o-phenylenediamine, p-hydroxybenzaldehyde, vanillin, veratraldehyde, anisaldehyde, sodium metabisulfite, N,N-dimethylformamide (DMF), ethyl acetate, $n$ hexane, ethanol and thin-layer chromatography (TLC) of silica gel $60 \mathrm{~F}_{254}$ (aluminum sheet). All chemicals were purchased and used without any purification from Merck.

A microwave oven (Sharp R-268R, W) was used to synthesize benzimidazoles 1-4. The structure of benzimidazoles 1-4 was determined using Fourier-Transform Infrared Spectroscopy (FT-IR) (Shimadzu Prestige-21 in KBr), Gas Chromatography-Mass Spectrometry (GC-MS) (Shimadzu QP-2010S, EI), ${ }^{1} \mathrm{H}$ $(500 \mathrm{MHz})$ and ${ }^{13} \mathrm{C}(125 \mathrm{MHz})$ Nuclear Magnetic Resonance (NMR) (JEOL JNM ECA 500; DMSO- $d_{6}$ as a solvent and internal standard of TMS). The uncorrected melting point was determined using Electrothermal 9100.

\section{General Procedure of Synthesis of Benzimidazoles}<smiles>[R]c1ccc(C=O)cc1[R]</smiles>
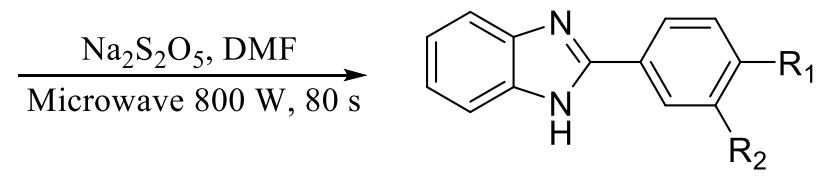

$$
\begin{aligned}
& \text { (1) } \mathrm{R}_{1}=\mathrm{R}_{2}=\mathrm{OCH}_{3} \\
& \text { (2) } \mathrm{R}_{1}=\mathrm{OH} ; \mathrm{R}_{2}=\mathrm{H} \\
& \text { (3) } \mathrm{R}_{1}=\mathrm{OCH} \mathrm{O}_{3} ; \mathrm{R}_{2}=\mathrm{H} \\
& \text { (4) } \mathrm{R}_{1}=\mathrm{OH} ; \mathrm{R}_{2}=\mathrm{OCH}_{3}
\end{aligned}
$$

Scheme-1: The Synthetic Reaction of 2-arylbenzimidazoles 1-4

In this experiment, 2-arylbenzimidazoles 1-4 were synthesized following the procedure by NavarreteVázquez et al. ${ }^{21}$ o-Phenylenediamine $(1 \mathrm{mmol})$, arylaldehyde $(1 \mathrm{mmol})$ and sodium metabisulfite $(1 \mathrm{mmol})$ was introduced in a glass vial. The mixture was added $0.1 \mathrm{~mL}$ of DMF was added to the vial and then irradiated with a household microwave oven for 80-90 s. The reaction was followed with TLC using an eluent mixture of ethyl acetate: $n$-hexane (1:1). After the reaction was complete, the reaction mixture was cooled, poured into water. The resulting solid was filtered off and then recrystallized from ethanol to obtain compounds 1-4.

\section{2-(3,4-dimethoxyphenyl)-1H-benzimidazole (1)}

Yield: $55 \%$, white solid, M.P. $223-225^{\circ} \mathrm{C}$ (Lit. $\left.235-236{ }^{\circ} \mathrm{C}\right) .{ }^{22} \mathrm{FTIR}(\mathrm{KBr}): \mathrm{cm}^{-1} 3410(\mathrm{~N}-\mathrm{H}), 1604(\mathrm{C}=\mathrm{N})$, $1504 \& 1435\left(\mathrm{C}=\mathrm{C}\right.$ aromatic), $1265(\mathrm{C}-\mathrm{O}) ;{ }^{1} \mathrm{H}$ NMR: $3.83(\mathrm{~s}, 3 \mathrm{H}), 3.88(\mathrm{~s}, 3 \mathrm{H}), 7.13(\mathrm{~d}, 1 \mathrm{H}), 7.18(\mathrm{t}, 2 \mathrm{H})$, 7.57 (d, 1H), $7.70(\mathrm{~s}, 1 \mathrm{H}), 7.75$ (s, 1H); ${ }^{13} \mathrm{C}$ NMR: 55.61, 109.68, 110.12, 111.81, 119.28, 121.84, 122.71, 148.07, 148.91, 150.29, 151.48; MS (m/z, EI): 254. 
2-(4-hydroxyphenyl)-1H-benzimidazole (2)

Yield: 52\%, orange solid, M.P. 266-270 ${ }^{\circ} \mathrm{C}$ (Lit. $\left.272{ }^{\circ} \mathrm{C}\right) .{ }^{23}$ FTIR $(\mathrm{KBr}): \mathrm{cm}^{-1} 3402(\mathrm{OH} \& \mathrm{~N}-\mathrm{H}), 1612$ $(\mathrm{C}=\mathrm{N}), 1450(\mathrm{C}=\mathrm{C}$ aromatic $), 1250(\mathrm{C}-\mathrm{O}) ; \mathrm{MS}(\mathrm{m} / \mathrm{z}, \mathrm{EI}): 210$.

\section{2-(4-methoxyphenyl)-1H-benzimidazole (3)}

Yield: $67 \%$, white solid, M.P. $224-226{ }^{\circ} \mathrm{C}$ (Lit. $\left.223-226{ }^{\circ} \mathrm{C}\right) \cdot{ }^{24.25}$ FTIR (KBr): $\mathrm{cm}^{-1} 3402(\mathrm{~N}-\mathrm{H}), 1612$ $(\mathrm{C}=\mathrm{N}), 1504 \& 1435(\mathrm{C}=\mathrm{C}$ aromatic) $1249(\mathrm{C}-\mathrm{O}) ; \mathrm{MS}(\mathrm{m} / \mathrm{z}, \mathrm{EI}): 224$.

\section{2-(4-hydroxy-3-methoxyphenyl)-1 $H$-benzimidazole (4)}

Yield:46\%, yellow light solid, M.P. 209-211 ${ }^{\circ} \mathrm{C}$ (Lit. 219-221 $\left.{ }^{\circ} \mathrm{C}\right){ }^{26} \mathrm{FTIR}(\mathrm{KBr}): \mathrm{cm}^{-1} 3309$ (N-H), 1597 $(\mathrm{C}=\mathrm{N}), 1504 \& 1442\left(\mathrm{C}=\mathrm{C}\right.$ aromatic), $1273 \& 1219(\mathrm{C}-\mathrm{O}) ;{ }^{1} \mathrm{H}$ NMR: $3.89(\mathrm{~s}, 3 \mathrm{H}), 6.92(\mathrm{~d}, 1 \mathrm{H}), 7.16(\mathrm{t}$, 2H), $7.54(\mathrm{~d}, 2 \mathrm{H}), 7.62(\mathrm{~d}, 1 \mathrm{H}), 7.74(\mathrm{~s}, 1 \mathrm{H}), 9.52(\mathrm{~s}, 1 \mathrm{H}) ;{ }^{13} \mathrm{C}$ NMR: 55.67, 110.34, 115.68, 119.69, 121.22, 121.69, 147.83, 148.51, 151.73; MS (m/z, EI): 240.

\section{Antimalarial Activity Assay}

The antimalarial activity was carried out according to previous methods against $P$.falciparum (3D7) strain. ${ }^{27}$

\section{Molecular Docking}

Molecular docking was conducted according to previous work by Syahri et al. ${ }^{28}$ Plasmodium falciparum dihydrofolate reductase-thymidylate synthase (PfDHFR-TS) protein (PDB ID: 1J3I.pdb) was used as the protein target. Interaction visualization was presented with Discovery Studio Visualizer software.

\section{Prediction of Lipinski's 'rule of 5'}

ChemDraw Professional 15.0 software and SwissADME web server (http://www.swissadme.ch/) were used to predict the drug-like and bioavailability of 2-arylbenzimidazoles with determining of $\log \mathrm{P}$ value, molecular weight, number of hydrogen bonds donor and acceptor.

\section{Synthesis of Benzimidazole Derivatives}

\section{RESULTS AND DISCUSSION}

In this study, 2-arylbenzimidazole derivates (1-4) have been obtained from the condensation of ophenylenediamine with substituted arylaldehyde under microwave irradiation using N,N-dimethylformamide (DMF) solvent and catalyst of sodium metabisulfitet (Scheme-1). DMF as a polar solvent was chosen and expected to optimize the energy absorption from the microwave. The reaction without a solvent was hard to complete because there was not enough energy to make all reactants became one phase (liquid). In contrast, if the DMF was added too much, it could lead to the formation of side products (impurities), which was also reported by Secci et al. ${ }^{29}$ The reaction under microwave irradiation was carried out for 80 90 seconds. In the process, after $10 \mathrm{~s}$ irradiation, the reaction mixture was taken out for cooling and then heated again at the same power level. This step was repeated every $10 \mathrm{~s}$ until the TLC indicated no starting materials left. It can be noticed that all prepared compounds indicated blue emission under UV irradiation. However, in extended heating times, several by-products were observed, and the targeted product can be carbonized. The most important result is the optimization of DMF solvent and time reaction can give good benzimidazoles products. The synthesis afforded the corresponding benzimidazole 1-4 in moderate yield. The compounds 1-4 were confirmed by data from previous literature and spectroscopic analysis (FT-IR, GC-MS, and NMR).

\section{Antimalarial Activity Assay}

In vitro antimalarial activity was studied toward the $P f 3 \mathrm{D} 7$ strain and the $\mathrm{IC}_{50}$ was presented in Table- 1 . The benzimidazole 3 is appeared to have good antimalarial activity followed by compounds $\mathbf{1}, \mathbf{2}$ and 4 . According to the criteria by Batista et al. ${ }^{30}$, compound 3 has an excellent activity $\left(\mathrm{IC}_{50}<1 \mu \mathrm{M}\right)$ while compounds 1,2 , and 4 were good activity $\left(\mathrm{IC}_{50}\right.$ of $\left.1-20 \mu \mathrm{M}\right)$. The $\mathrm{IC}_{50}$ of 2 -arylbenzimidazoles $1-4$ are still higher than $\mathrm{IC}_{50}$ of chloroquine (CQ). However, this result indicates that compound $\mathbf{3}$ was the best candidate for the antimalarial drugs based on the in vitro assay against Pf3D7 strain. 
Vol. 14 | No. 1 |94-100| January - March | 2021

Table-1: Antimalarial Activity ( $\mathrm{IC}_{50}$ ) of Compound 1-4 and Positive Control CQ

\begin{tabular}{c|c|c}
\hline \multirow{2}{*}{ Compound } & \multicolumn{2}{|c}{$\mathrm{IC}_{50}$ against $P f 3 \mathrm{D} 7$} \\
\cline { 2 - 3 } & $(\mu \mathrm{g} / \mathrm{ml})$ & $\mu \mathrm{M}$ \\
\hline 1 & 0.33 & 1.298 \\
\hline 2 & 0.88 & 4.186 \\
\hline 3 & 0.17 & 0.758 \\
\hline 4 & 2.57 & 10.697 \\
\hline $\mathrm{CQ}$ & 0.02 & 0.0625 \\
\hline
\end{tabular}

This study also suggested the importance of the methoxy group to improve antimalarial activity. The presence of methoxy in the para position of 2-aryl substitution (compound 3) gave the best antimalarial activity. However, compound $\mathbf{1}$ with dimethoxy substituents (meta-para) displayed lower antimalarial activity. Furthermore, changing the methoxy with the hydroxyl group lowered significantly the antiplasmodial activity of compounds 2 and 4 .

\section{Molecular Docking Studies}

Molecular docking was studied with CDOCKER method to the wild-type PfDHFR-TS protein (1J3I.pdb). PfDHFR is known as a protein target in the development of the antifolate antimalarial drug. Table- 2 presented the CDOCKER energy and also interactions formed to the binding site of PfDHFR-TS protein (1J3I.pdb).

The molecular docking results were consistent with the trend of data for in vitro activity. Compound 3 showed the best CDOCKER energy by $-39.06 \mathrm{kcal} / \mathrm{mol}$, compared with the native ligand WR99210 that generates CDOCKER energy of $-54.32 \mathrm{kcal} / \mathrm{mol}$. Meanwhile, benzimidazoles 1, 2, and 4 displayed higher energy (more than $-34 \mathrm{kcal} / \mathrm{mol})$. WR99210 (1,3,5-triazine derivatives) was used as the reference ${ }^{31}$. This result means that benzimidazole 3 has the most stable interaction with the molecule target PfDHFR-TS protein (1J3I.pdb).

Table-2: Molecular Docking of Compound 1-4 and Native Co-crystal Ligand WR99210

\begin{tabular}{c|c|l}
\hline Compound & $\begin{array}{c}\text { CDOCKER Energy } \\
\text { (kcal/mol })\end{array}$ & \multicolumn{1}{c}{ Interactions } \\
\hline 1 & -35.97 & $\begin{array}{l}\text { Hydrogen bonds: ILE164, TYR170, SER108, } \\
\text { GLY44. } \\
\pi: \text { ALA16 }\end{array}$ \\
\hline 2 & -34.12 & $\begin{array}{l}\text { Hydrogen bonds: ILE164, TYR170, SER108. } \\
\pi: \text { ALA16, PHE58 }\end{array}$ \\
\hline 3 & -39.06 & $\begin{array}{l}\text { Hydrogen bonds: ILE164, TYR170, SER108, } \\
\text { GLY44. } \\
\pi: \text { ALA16, PHE58 }\end{array}$ \\
\hline CQ & -29.93 & $\begin{array}{l}\text { Hydrogen bonds: TYR170, SER108 } \\
\pi: \text { ILE112, LEU46 } \\
\text { *nt }\end{array}$ \\
\hline *nt: not tested & $*$ nt & $\begin{array}{l}\text { Hydrogen bonds: ALA16, ILE164, PHE58, TYR170, } \\
\text { SER108, ILE14, ASP54, CYS15 } \\
\pi: \text { LEU164, MET55 }\end{array}$ \\
\hline
\end{tabular}

The native co-crystal ligand WR99210 was reported to have key interaction to the important sites of the wild-type $P f$-DHFR protein such as ILE14, ALA16, MET55, ASP54, SER108, ILE164, and TYR170. ${ }^{32}$ Compound 3 displayed the hydrogen bonds to the essential amino acid ILE164, TYR170, SER108, and $\pi$ bonds to ALA16 and PHE58 (Fig.-1). This study proposed the importance of interaction with GLY44 and PHE58 amino acids to determine the antimalarial activity. The presence of the interaction toward GLY44 (compound 3), significantly increases the antimalarial activity compared with compound 2 . Hadni and Elhallaoui ${ }^{33}$ have reported that additional interaction with GLY44 was observed in the docking result of the best active anilinoquinoline-triazine derivatives with binding pocket of $P f$-DHFR. Meanwhile, interaction 
with PHE58 could increase antimalarial activity by twofold (compounds $\mathbf{1}$ and $\mathbf{3}$ ). Moreover, the absence of interaction with ALA16, ILE164, TYR170, SER108, GLY44, and PHE58 could lower the antimalarial activity (compound $\mathbf{4}$ ). Thus, compound $\mathbf{3}$ was confirmed to be the best antimalarial drug candidate.

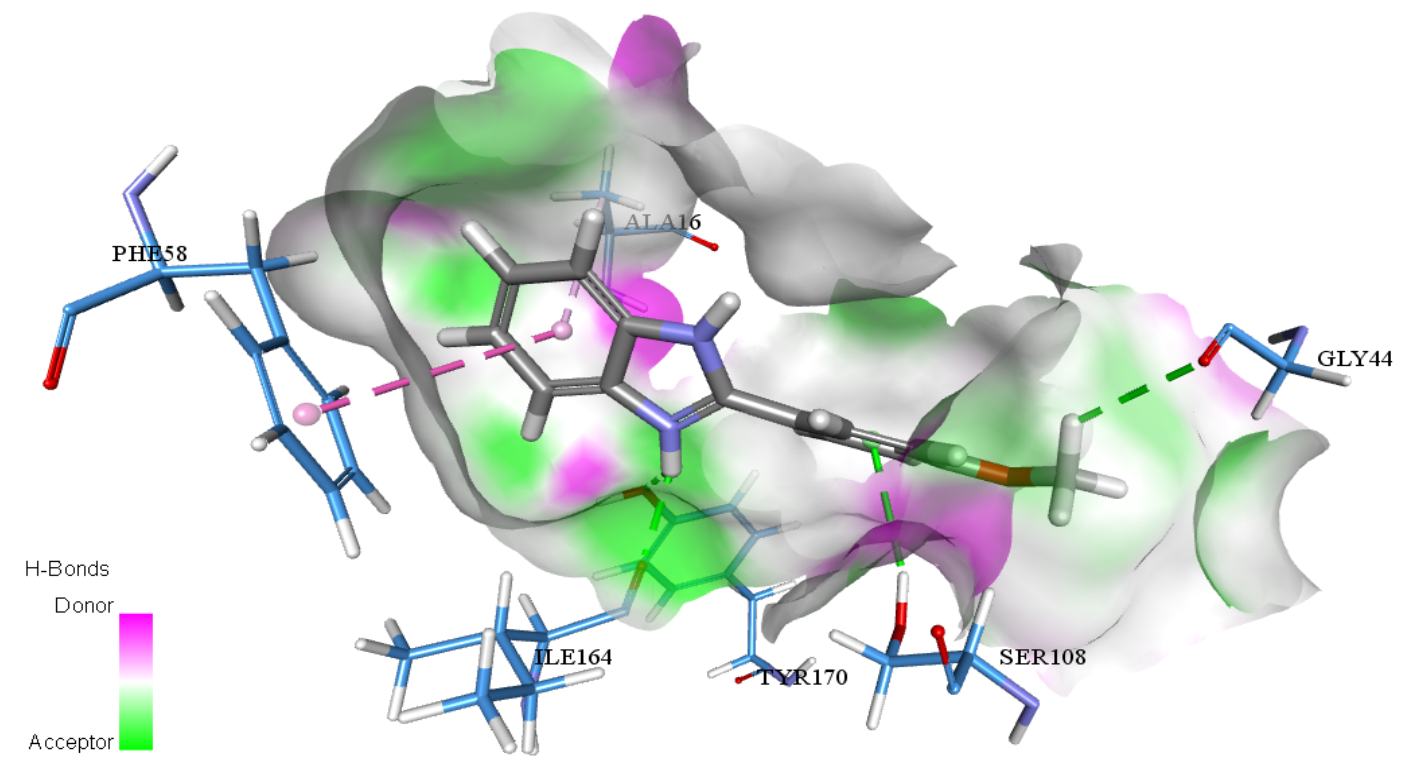

Fig.-1: Docking of 2-arylbenzimidazole 3 to the amino acid for PfDHFR-TS protein (1J3I.pdb). The carbon atom is visualized in grey, nitrogen in purple, hydrogen in white, and oxygen in red color. Green and pink lines displayed interaction via hydrogen and $\pi$ bonds respectively.

\section{Pharmacological Evaluation}

Analyses ADME were used to predict the bioavailability of compounds 1-4 using Lipinski's 'rule of 5'. The rule is used as a guideline to predict drug-like properties for small molecules from an oral bioavailability aspect. ${ }^{34}$ This rule suggests that violation of two or more of the rules might lead to the poor solubility and permeability of the molecules. ${ }^{35}$ Result showed that all the prepared 2-arylbenzimidazole 14 have good pharmacokinetics parameters with molecular weight less than $500, \log \mathrm{P}$ value $<5$, number of hydrogen bonds for both donor and acceptor is $<5$ (Table-3). Based on this study, 2-arylbenzimidazole derivatives can be proposed as the antimalarial agents' candidate as it displayed excellent and good in vitro antimalarial activity, supported by the molecular docking and also prediction of the druglike properties.

\begin{tabular}{c|c|c|c|c}
\multicolumn{2}{c}{ Table-3: Pharmacokinetics Parameters of 2-arylbenzimidazoles (1-4) } \\
\hline Comp. & $\begin{array}{c}\text { Molecular } \\
\text { weight } \\
(\mathrm{g} / \mathrm{mol})\end{array}$ & $\begin{array}{c}\text { logP } \\
\text { (lipophilicity) } \\
<5\end{array}$ & $\begin{array}{c}\text { Hydrogen } \\
\text { bond donor } \\
<5\end{array}$ & $\begin{array}{c}\text { Hydrogen } \\
\text { bond acceptor } \\
<5\end{array}$ \\
\hline 1 & 254.28 & 2.88 & 1 & 3 \\
\hline 2 & 210.23 & 2.52 & 2 & 2 \\
\hline 3 & 224.26 & 2.91 & 2 & 2 \\
\hline 4 & 240.26 & 2.57 & 2 & 3 \\
\hline CQ & 319.87 & 4.15 & 1 & 2 \\
\hline
\end{tabular}

CONCLUSION

Four 2-arylbenzimidazoles compounds (1-4) have been successfully synthesized using microwave irradiation, tested in vitro antimalarial assay, studied the molecular docking and pharmacological evaluation based on Lipinski's 'rule of 5. The benzimidazole 3 has excellent activity while compounds 1, 2, and 4. have good antimalarial activity. All the benzimidazoles 1-4 showed druglike properties.

\section{ACKNOWLEDGMENT}

This study was supported by The Grant from BPPTNBH, Faculty of Mathematics and Natural Sciences, Universitas Gadjah Mada with contract number: 69/J01.L28/PL.06.02/2019 date April, 11 ${ }^{\text {st }}, 2019$. 
Vol. 14 | No. 1 |94-100| January - March | 2021

\section{REFERENCES}

1. World Health Organization (WHO), World Malaria Report: 2016, WHO Library Cataloguing-inPublication Data, Geneva (2017).

2. World Health Organization (WHO), World Malaria Report: 2018. WHO Press, Geneva, Switzerland (2019).

3. K. Haldar, S. Bhattacharjee and I. Safeukui, Nature Reviews Microbiology, 16(3), 156(2018), DOI:10.1038/nrmicro.2017.161

4. Malaria Policy Advisory Committee to the WHO: Conclusions and Recommendations of Sixth Biannual Meeting (September 2014), Malaria Journal, 14, 107(2015), DOI:10.1186/s12936-0150623-5

5. A. Patil, S. Ganguly, and S. Surana, Rasayan Journal of Chemistry, 1(3), 447(2008).

6. A. Kamil, S. Akhter, M. Ahmed, G.H. Rizwani, S. Hassan, S. Naeem, S. Jahan, R. Khursheed and H. Zahid, Pakistan Journal of Pharmaceutical Science, 28(6), 2179(2015).

7. Z.S. Saify, M.K. Azim, W. Ahmad, M. Nisa, D.E. Goldberg, S.A. Hussain, S. Akhtar, A. Akram, A. Arayne, A. Oksman and I.A. Khan, Bioorganic \& Medicinal Chemistry Letter, 22(2), 1282(2012), DOI: $10.1016 / \mathrm{j} . \mathrm{bmcl} .2011 .10 .018$

8. Salahuddin, M. Shaharyar and A. Mazumder, Arabian Journal of Chemistry, 10(1), S157(2017), DOI:10.1016/j.arabjc.2012.07.017

9. P. S. Misra, P. Shanmugasundaram, R. Chaudhary, and M.V. Aanandhi, Rasayan Journal of Chemistry, 3(1), 5(2010).

10. R. Mueller, V. Reddy, A.T. Nchinda, F. Mebrahtu, D. Taylor, N. Lawrence, L. Tanner, M. Barnabe, C.J. Eyermann, B. Zou, R.R. Kondreddi, S.B. Lakshminarayana, M. Rottmann, L.J Street and K. Chibale, ACS Omega, 5(12), 6967(2020), DOI: 10.1021/acsomega.0c00327

11. J. Camacho, A. Barazarte, N. Gamboa, J. Rodrigues, R. Rojas, A. Vaisberg, R. Gilman and J. Charris, Bioorganic \& Medicinal Chemistry, 19(6), 2023(2011), DOI:10.1016/j.bmc.2011.01.050

12. E. Cichero, M. Tonelli, F. Novelli, B. Tasso, I. Delogu, R. Loddo, O. Bruno and P. Fossa, Journal of Enzyme Inhibition and Medicinal Chemistry, 32(1), 375(2017), DOI:10.1080/14756366.2016.1256881

13. R. Srivastava, S.K. Gupta, F. Naaz, A. Singh, V.K. Singh, R. Verma, N. Singh and R.K. Singh, Computational Biology and Chemistry, 76, 1(2018), DOI:10.1016/j.compbiolchem.2018.05.021

14. K. Sharma, A. Shrivastava, R.N. Mehra, G.S. Deora, M.M. Alam, M.S. Zaman and M. Akhter, Archiv der Pharmmazie (Weinheim), 351(1), 1700251(2018), DOI:10.1002/ardp.201700251

15. K. Patel, C. Karthikeyan, N.S.H.N. Moorthy, G.S. Deora, V.R. Solomon, H. Lee and P. Trivedi, Medicinal Chemistry Research, 21(8), 1780(2012), DOI:10.1007/s00044-011-9694-1

16. J. Syahri, E. Yuanita, B.A. Nurohmah, R. Armunanto and B. Purwono, Asian Pacific Journal of Tropical Biomedicine, 7(8), 675(2017), DOI:10.1016/j.apjtb.2017.07.004

17. Schneider G. Prediction of Drug-Like Properties. In: Madame Curie Bioscience Database [Internet]. Austin (TX): Landes Bioscience; 2000-2013. Available from: https://www.ncbi.nlm.nih.gov/books/NBK6404/

18. S. Tahlan, S. Kumar, K. Ramasamy, S.M. Lim, S.A.A. Shah, V. Mani and B. Narasimhan, BMC Chemistry, 13(1), 90(2019), DOI:10.1186/s13065-019-0608-5

19. N.Ö. Can, U.A. Çeik, B.N. Sağlık, Y. Özkay, Ö. Atl1, M. Baysal, Ü. D. Özkay and Ö.D. Can, Molecules, 22(8), 1374(2017), DOI:10.3390/molecules22081374

20. M. Rashid, Bioorganic Chemistry, 96, 103576(2020), DOI:10.1016/j.bioorg.2020.103576

21. G. Navarrete-Vázquez, H. Moreno-Diaz, F. Aguirre-Crespo, I. León-Rivera, R. Villalobos-Molina, O. Muñoz-Muñiz and S. Estrada-Soto, Bioorganic \& Medicinal Chemistry Letter, 16(16), 4169(2006), DOI:10.1016/j.bmcl.2006.05.082

22. G. Navarrete-Vázquez, H. Moreno-Diaz, S. Estrada-Soto, M. Torres-Piedra, I. León -Rivera and H. Tlahuext, Synthetic Communications, 37, 2815(2007), DOI:10.1080/00397910701473325

23. D.T. Nannapaneni, A. Gupta, M.I. Reddy and R.Ch. Sarva, Research Journal of Pharmacy and Technology, 11, 221(2018), DOI:10.4103/0975-1483.66809

24. M. Lei, L. Ma and L. Hu, Synthetic Communications, 42, 2981(2012), DOI: $10.1080 / 00397911.2011 .573610$ 
RASĀYAN J. Chem.

Vol. 14 | No. 1 |94-100| January - March | 2021

25. G. C. Wadhawa, V. S. Shivankar, S.S. Patil, Y. A. Gaikwad, A. V. Satere, B. Rode, C. H. Gill, and L. V. Gavali, Rasayan Journal of Chemistry, 10(1), 13(2017), DOI:10.7324/ RJC.2017.1011494

26. Z. Mao, Z. Wang, J. Li, X. Song and Y. Luo, Synthetic Communications, 40, 1963(2010), DOI:10.1080/00397910903219328

27. J. Syahri, H. Nasution, B.A. Nurohmah, B. Purwono and E. Yuanita, Journal of Applied Pharmaceutical Science, 10(06), 1(2020), DOI:10.7324/JAPS.2020.10601

28. J. Syahri, H. Nasution, B.A. Nurohmah, B. Purwono, E. Yuanita and N.I. Hassan, Sains Malaysiana, 49(11), 2667(2020), DOI:10.17576/jsm-2020-4911-06

29. D. Secci, A. Bolasco, M. D'Ascenzio, dF. Sala, M. Yanez and S. Carradori, Journal of Heterocyclic Chemistry, 49(5), 1187(2012), DOI:10.1002/jhet.1058

30. R. Batista, A.J.S. Junior and A.B. Oliveira, Molecules, 14(8), 3037(2009), DOI: $10.3390 /$ molecules 14083037

31. M.D. Hastings and C.H. Sibley, In Proceedings of the National Academy of Sciences of the United States of America, 99(20), 13137(2002), DOI:10.1073/pnas.182295999

32. J. Yuvaniyama, P. Chitnumsub, S. Kamchonwongpaisan, J. Vanichtanankul, W. Sirawaraporn, P. Taylor, M.D. Walkinshaw and Y. Yuthavong, Nature Structural \& Molecular Biology, 10(5), 357 (2003), DOI:10.1038/nsb921

33. H. Hadni and M. Elhallaoui, Heliyon, 5(8), e02357 (2019), DOI:10.1016/j.heliyon.2019.e02357

34. T.I. Oprea, Journal of Computer-Aided Molecular Design, 14, 251(2000), DOI:10.1023/a:1008130001697

35. C.A. Lipinski, Journal of Pharmacological and Toxicological Methods, 44, 235(2000), DOI:10.1016/s1056-8719(00)00107-6

[RJC-6088/2020] 